\title{
СИНТЕЗ КАНАЛА ПРИНУДИТЕЛЬНОЙ ПЕРЕСТРОЙКИ ЧАСТОТЫ СЛЕДЯЩЕГО ДОПЛЕРОВСКОГО ФИЛЬТРА
}

\author{
ПЕЧЕНИН В. В. ${ }^{1}$, ЩЕРБИНА К. А. ${ }^{1}$, ВОЙТЕНКО О. В. ${ }^{2}$ \\ ${ }^{1}$ Наичональный аэрокосмический университет им. Н. Е. Жуковского \\ «Харьковский Авиационный Институт», \\ Украина, Харьков, 61070, ул. Чкалова, 17 \\ ${ }^{2}$ Житомирский военный институт им. С. П. Королева национального авиационного университета, \\ Украина, Житомир, 10004, пр-т Мира, 22
}

\begin{abstract}
Аннотация. Приведены результаты разработки канала принудительной перестройки частоты следящего доплеровского фильтра, в котором применен управляющий генератор с внешней синхронизацией. Дано теоретическое описание, функциональные схемы фильтра, метод построения и реализации частотного дискриминатора, обеспечивающего существенно лучшие характеристики по сравнению с существующими и примерно одинаковые флуктуационные погрешности при коэффициенте фильтрации $k_{\phi}>15-20$. Рабочий диапазон принудительной перестройки частоты канала составляет 0,01-2 МГц при высокой линейности дискриминационной характеристики в интервале частотных изменений $\left|f / f_{0}\right|=0,8$ и температурной стабильности крутизны $1,5 \%$ в интервале температур от -60 до $+60{ }^{\circ} \mathrm{C}$. Приведены основные аналитические соотношения, пригодные для аналитических расчетов
\end{abstract}

Ключевые слова: летательный аппарат; фильтр нижних частот; эффект Доплера; точность; отношение сигнал/шум; электромагнитные волны

\section{ВВЕДЕНИЕ}

Следящий доплеровский фильтр (СДФ) является составной частью измерительной радиотехнической системы, определяющей скоростные параметры радиолокационной цели по результатам измерений доплеровской частоты принимаемых сигналов в процессе их спектрального анализа. Информационное содержание доплеровского спектра отраженных от цели сигналов подробно изложено в [1]. Необходимость использования принудительной перестройки (подстройки) СДФ обусловлена возросшими скоростями и маневренными характеристиками современных летательных аппаратов [2].
Большинство существующих и применяемых на практике СДФ реализованы на основе систем фазовой автоподстройки частоты, частотной автоподстройки частоты и частотно-фазовой автоподстройки частоты [3]. В качестве перспективных СДФ возможно использовать комбинированные радиотехнические системы автоматического управления [4]. Менее изученными в плане практического использования являются СДФ, реализуемые на основе синхронизации управляемого генератора (УГ) входным доплеровским сигналом и принудительной перестройкой по частоте сигналом управления, формируемым из изменяющегося по частоте входного сигнала [5].

В настоящей работе рассматриваются особенности синтеза канала принудительной пе- 